\title{
REE patterns in diamond bearing eclogites and diamond bearing peridotites from Newlands kimberlite
}

Menzies, A.H. ${ }^{1}$, Gurney, J.J. ${ }^{1}$, Harte, B. ${ }^{2}$, and Hauri, E. ${ }^{3}$

1 Department of Geological Sciences, University of Cape Town, Rondebosch 7700, South Africa

2 Grant Institute of Geology, University of Edinburgh, Edinburgh, EH9 3JW, United Kingdom

3 Department of Terrestrial Magnetism, Carnegie Institute of Washington, 5241 Broad Branch Road NW, Washington D.C. 20015, U.S.A.

This study reports the first REE patterns for a suite of diamondiferous garnet harzburgites from the Kaapvaal craton. A range of non-diamondiferous peridotites and eclogites from Newlands were also analysed for comparison. The Newlands kimberlite cluster is a member of the Barkly West group located NW of Kimberley, South Africa. It is of Group II affinity and dated at $\sim 114 \mathrm{Ma}$ (Smith et al., 1985). Details of the Newlands kimberlite and its xenoliths are described by Menzies (1998) and Gurney and Menzies (1998). Samples were analysed at Grant College (Edinburgh University) and the Carnegie Institute of Washington using the Cameca IMF $4 \mathrm{f}$ and Cameca IMF 6 f, respectively.

\section{Eclogites:}

The eclogites can be divided into five groups on the basis of hand specimen observations of over 40 specimens. Statistical analysis using Principal Component Analysis (PCA) on major and trace element mineral chemistry supports these groupings (figure 1a). Only Group E is diamond-bearing and is similar to Group D (not shown in figure 1a) in mineral chemistry and hand specimen except for the presence of diamond. In this study 10 diamond-bearing eclogites were analysed and one from each of Groups A, B, and C for comparison (see figure 1a,b,c).

The garnets and clinopyroxenes from diamond-bearing eclogites display remarkably similar REE patterns, with normalised REE ([REE $]_{n}$ ) variations between samples all within a factor of two (figure $1 \mathrm{~b}$ and $1 \mathrm{c}$ ). Even sample AHM K8, which is the only diamond-bearing eclogite to display a major and trace element chemistry different to the other diamond-bearing samples (see figure 1a), has a similar REE pattern. Group A eclogites have a very similar garnet and clinopyroxene pattern to diamond-bearing eclogites, however there are subtle differences. The garnets display a slightly higher $[\mathrm{La}]_{\mathrm{n}}$ and MREE pattern while the clinopyroxenes also have a marginally higher $[\mathrm{La}]_{\mathrm{n}}$ and lower HREE pattern. PCA using major and trace elements (but excluding REEs) associates sample AHM K8 with Group A eclogites. This is also observed in the REE pattern, with AHM K8 displaying the subtle differences shown by Group A eclogites as well as being noticeably lower in HREEs. The $[\mathrm{La}]_{\mathrm{n}}$ is a factor of two higher for both Group A eclogites and sample AHM K8 over diamond-bearing eclogites. Group B eclogites display higher LREEs in the garnets and lower HREEs in the clinopyroxene relative to diamond-bearing specimens. In contrast, Group C eclogites are highly depleted in all REE's compared to other groups. The various eclogitic groups can also be recognised on the basis of garnet and clinopyroxene REE patterns.

The diamond-bearing eclogites from Newlands do not display the REE variation observed in diamond-bearing eclogites in, for example, the Yakutian kimberlite field (Snyder et al., 1997 and references therein).They do, however, have similar REE patterns to the 'typical' clinopyroxenes and garnets identified by Snyder et al. (1997) except that the $(\mathrm{La} / \mathrm{Nd})_{n}$ ratio is slightly higher (clinopyroxene: 1.2 to 1.3 ; garnet: 0.10 to 0.15 ). The clinopyroxenes from non diamond-bearing eclogites and sample AHM K8 plot along a Sr/Nd mantle array ( 20, O’Nions, 1987). In contrast, 

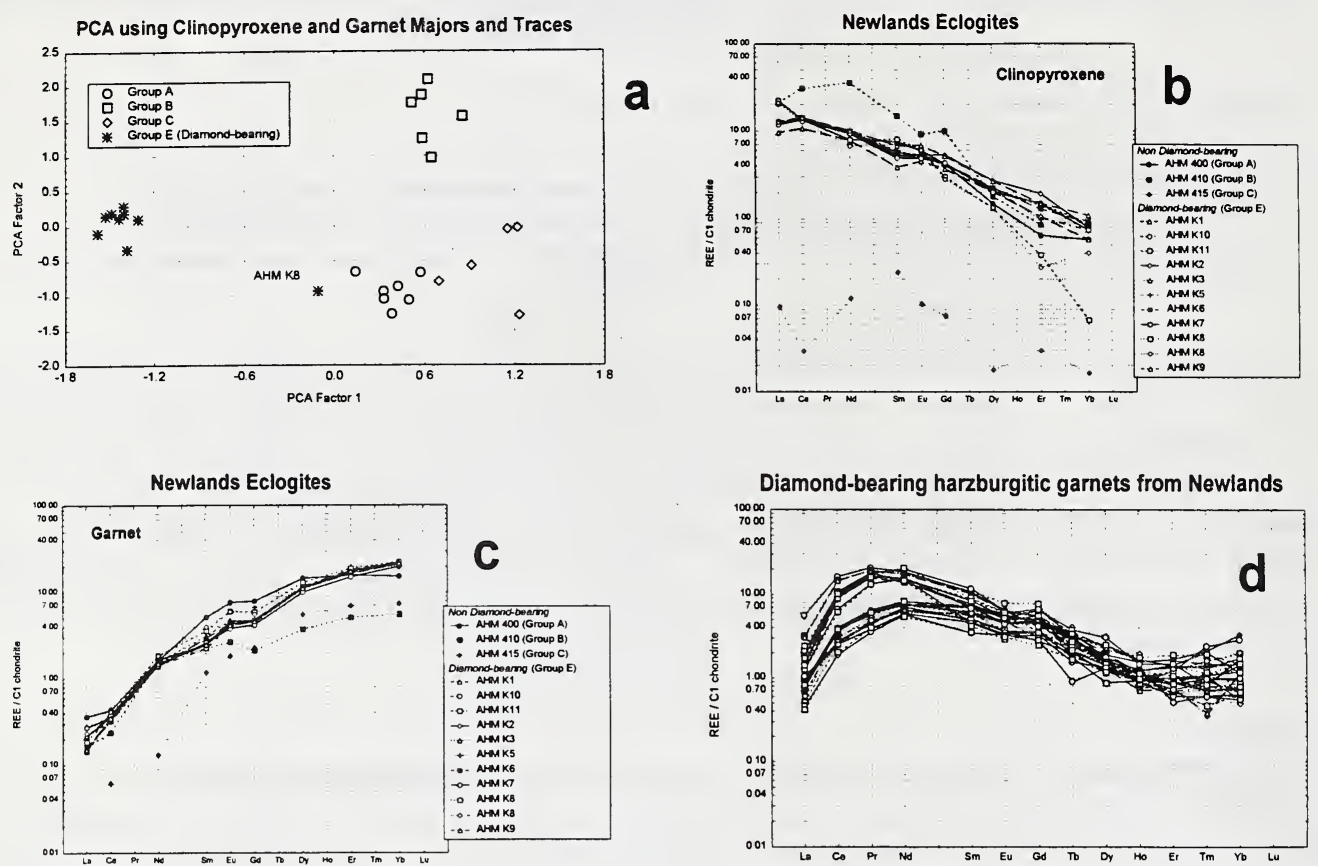

Figure 1 (a) Various Eclogitic groups identified using Principal Component Analysis.

(b) REE patterns for clinopyroxenes from Newlands eclogites.

(c) REE patterns for garnets from Newlands eclogites.

(d) REE patterns for various diamond-bearing harzburgitic garnets from Newlands.

the diamond-bearing eclogites plot along an array several orders of magnitude higher, and has been observed in diamond-bearing eclogites (Snyder et al., 1997) and diamond inclusions (Sobolev et al., 1996) from Yakutia. They interpret this enrichment event as ancient metasomatism from a carbonitite magma or fluid that pre-dates diamond formation. The diamond-bearing eclogitic xenoliths from Newlands are $3.56 \mathrm{Ga}$ (using Re-Os, see Menzies et al, this volume) and therefore these signatures may be related to early Archaean events and stabilisation of the continental lithosphere.

\section{Peridotites:}

The diamond-bearing garnets are high-Cr subcalcic G10's which overlap the world-wide peridotitic diamond inclusion field. Garnets from two diamond-bearing lherzolites were also analysed. The garnets are high $\mathrm{Cr}$ and plot at the transect of the Newlands lherzolitic trend and the high- $\mathrm{Cr}$ subcalcic trend (Menzies, 1998).

The ten diamond-bearing harzburgitic garnets and two diamond-bearing lherzolitic garnets analysed display the "classic" sinusodal LREE enriched pattern (figure 1d) first observed in diamond inclusions and garnet concentrates by Shimizu and Richardson (1987). The garnets show no significant internal zonation, as observed in diamond inclusions from Siberia (Shimizu and Sobolev, 1995). The shape of the REE patterns are all very similar and $[R E E]_{n}$ vary within one order of magnitude between samples (see figure 1d). However there are subtle differences. All the diamond-bearing harzburgitic garnets have a LREE peak at $[\mathrm{Pr}]_{\mathrm{n}}$ or $[\mathrm{Nd}]_{\mathrm{n}}$ and display a prominent 
[Gd] "kick" with HREE either remaining flat or increasing slightly. In contrast, the two lherzolite specimens, which contain diamond and graphite respectively, have the LREE enrichment peak at $[\mathrm{Sm}]_{\mathrm{n}}$ and have a smooth decreasing MREE pattern. Also, the diamond-bearing harzburgite garnets can be divided into two groups on the basis of LREE enrichment, namely those with $[\mathrm{Pr}]_{\mathrm{n}}$ and $[\mathrm{Nd}]_{\mathrm{n}}$ above or below 10 (see figure 2). The signatures identified are similar to those observed elsewhere, for example in Russia (Shimizu and Sobolev, 1996) and southern Africa (Nixon, 1987; Shimizu and Richardson, 1987). The harzburgitic garnets are also enriched in $\mathrm{Sr}$ and depleted in $\mathrm{Y}, \mathrm{Ti}, \mathrm{Zr}$ and Ga relative to lherzolitic garnets at Newlands (Menzies et al., 1996). This signature has been noted elsewhere for garnet inclusions in diamonds from the Kaapvaal and Siberian cratons (Griffin et. al., 1992, 1993).

The similarity between harzburgitic garnets in diamond-bearing macrocrysts from Newlands and diamond inclusions from other studies suggests that both may record information about original equilibrium formation conditions. Peridotites from Newlands, including the diamond-bearing macrocrysts, are mid- to late- Archaean in age (Menzies et al., 1998). FTIR studies on the Newlands peridotitic diamonds (Menzies et al., this volume) are consistent with diamond ages similar to these peridotite ages. These observations support the Archaean diamond ages based on isotope modelling proposed by Richardson et al. (1984).

\section{References}

Gurney, J.J., and Menzies, A.H., 1998, Small Mines Field Guide (7IKC): (in press)

Griffin, W.J., Gurney, J.J., and Ryan, C.G., 1992, Variations in trapping temperatures and trace elements in peridotiticsuite inclusions from African diamonds: evidence for two inclusion suites, and implications for lithosphere stratigraphy: Contrib. Min. Petrol., v. 110, p. 1-15 et. al., 1992.

Griffin, W.J, Sobolev, N.V., Ryan, C.G, Pokhilenko, N.P., Win, T.T., and Yefimova, E.S., 1993, Trace elements in garnets and chromites: Diamond formation in the Siberian lithosphere: Lithos, v29, p. 235-256.

Menzies, A.H, 1998, Unpub. Thesis (in prep.)

Menzies, A.H., Milledge, H.J.M, and Gurney, J.J., 1998, Fourier Transform Infra-red (FTIR) Spectroscopy of Newlands diamonds: (this volume).

Menzies, A.H., Shirey, S.B., Carlson, R.W, and Gurney, J.J, 1998, Re-Os isotope systematics of diamond-bearing eclogites and peridotites from Newlands Kimberlite: (this volume).

Menzies, A.H., Prozesky, V.,Przybylowicz, W., and Gurney, J.J., 1996, Detailed trace element studies of diamondbearing xenoliths from Newlands kimberlite: N.A.C. Annual report, p. 69-70.

Richardson, S.H., Gurney, J.J., Erlank, A.J., and Harris, J.W., 1984, Origin of diamonds in old enriched mantle: Nature, 310, p. 198-202.

Nixon, P.H., van Calsteren, P.W.C., Boyd, F.R., and Hawkesworth , C.J., 1987, Harzburgites with garnets of diamond facies from southern African kimberlites, in Nixon, P.H. ed., Mantle Xenoliths: Chichester, J. Wiley and Sons, pp. 523533.

O’Nions, R.K., 1987, Relationships between chemical and convective layering in the Earth: J. Geo. Soc. London, 144, p. $259-274$.

Smith, C.B., Gurney, J.J, Skinner, E.M.W., Clement, C.R., and Ebrahim, N., 1985, Geochemical character of southern African kimberlites: a new approach based on isotopic constraints: Trans. Geol. Soc. Sth. Africa, 88, p. 267-280.

Shimizu, N., and Richardson, S.H., 1987, Trace element abundance patterns of garnet inclusions in peridotitic-suite diamonds: Geochim. Cosmochim. Acta, v.51, p.755-758.

Shimuzu, N, and Sobolev, N.J., 1995, Young peridotitic diamonds from the Mir kimberlite: Nature, v75, p. 394-397.

Snyder, G.A, Taylor, L.A, Crozaz, G., Halliday, A.N., Beard, B.L., Sobolev, N.Z., and Sobolev, N.V., 1997, The origins of Yakutian Eclogite Xenoliths: J. Petrol., v38, p. 85-113.

Sobolev, N.J., Yefimova, E.S., Taylor, L.A., Snyder, G.A., and Sobolev, V.N., 1996, Major and trace element variations in multiple eclogitic inclusions in individual diamonds from Yakutia, Russia: Trans. Am. Geo. Union, v77. 